\title{
SUS-30 years: right and access in a day in the life of Primary Health Care
}

\author{
SUS-30 anos: direito e acesso no cotidiano da Atenção Primária à Saúde \\ SUS-30 años: derecho y acceso en el cotidiano de la Atención Primaria de Salud
}

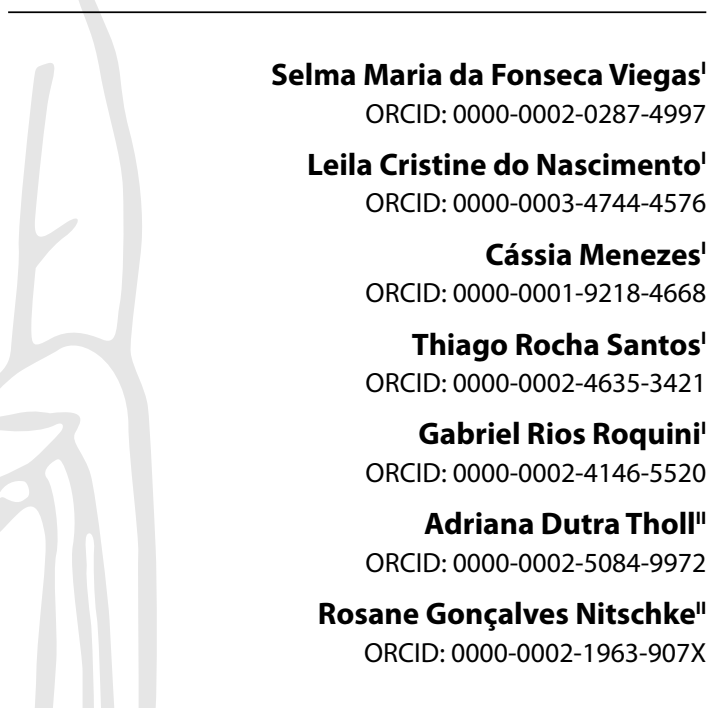

'Universidade Federal de São João del-Rei. Divinópolis, Minas Gerais, Brazil.

"Universidade Federal de Santa Catarina. Florianópolis, Santa Catarina, Brazil.

How to cite this article: Viegas SMF, Nascimento LC, Menezes C, Santos TR, Roquini GR, Tholl AD, et al. SUS-30 years: right and access in a day in the life of Primary Health Care.

Rev Bras Enferm. 2021;74(2):e20200656.

https://doi.org/10.1590/0034-7167-2020-0656

Corresponding author:

Selma Maria da Fonseca Viegas

E-mail: selmaviegas@ufsj.edu.br

EDITOR IN CHIEF: Antonio José de Almeida Filho

ASSOCIATE EDITOR: Priscilla Valladares Broca

\section{ABSTRACT}

Objectives: to understand access in a day in the life Primary Health Care as a fundamental right to health, from users' perspective. Methods: a holistic-qualitative multiple case study based on Comprehensive Sociology of Everyday Life. 77 Unified Health System (SUS) users participated in the study. Results: according to users' voice, the right to health is still a matter of struggle, in more than 30 years of SUS. SUS is considered as the place where they have to appeal. The experiences are diverse, from the ease to the difficulty of access, neglecting users' needs, but despite the inequality in relation to the offer of services, the solution always arrives. Final Considerations: to overcome this historical obstacle of comprehensive access to health, as a fundamental human right, it is necessary to overcome political and administrative decisions that hinder the construction of legitimate SUS, in a truly democratic participation of all social actors.

Descriptors: Right to Health; Health Services Accessibility; Primary Health Care; Unified Health System; Nursing.

\section{RESUMO}

Objetivos: compreender acesso no cotidiano da Atenção Primária à Saúde como direito fundamental à saúde, sob a ótica do usuário. Métodos: estudo de casos múltiplos holísticoqualitativo, fundamentado na Sociologia Compreensiva do Cotidiano. Participaram do estudo 77 usuários do Sistema Único de Saúde (SUS). Resultados: na voz dos usuários, o direito à saúde ainda é uma questão de luta em mais de 30 anos de SUS. O SUS é considerado como o lugar onde eles têm para recorrer. As vivências se apresentam diversas, da facilidade à dificuldade de acesso, no descaso frente às necessidades dos usuários, mas apesar da desigualdade em relação à oferta de serviços, a solução sempre chega. Considerações Finais: para superar esse obstáculo histórico de acesso integral à saúde, como direito humano fundamental, é preciso superar decisões políticas e administrativas que impedem a construção do SUS legítimo, em uma participação verdadeiramente democrática de todos os atores sociais. Descritores: Direito à Saúde; Acesso aos Serviços de Saúde; Atenção Primária à Saúde; Sistema Único de Saúde; Enfermagem.

\section{RESUMEN}

Objetivos: comprender el acceso en la rutina de la Atención Primaria de Salud como un derecho fundamental a la salud, desde la perspectiva del usuario. Métodos: estudio de caso múltiple holístico-cualitativo, basado en la Sociología Integral de la Vida Cotidiana. En el estudio participaron 77 usuarios del Sistema Único de Salud (SUS). Resultados: en la voz de los usuarios, el derecho a la salud sigue siendo un tema de lucha en más de 30 años del SUS. Se considera que el SUS es el lugar donde tienen que apelar. Las experiencias son diversas, desde la facilidad hasta la dificultad de acceso, descuidando las necesidades de los usuarios, pero a pesar de la desigualdad en relación a la oferta de servicios, la solución siempre llega. Consideraciones Finales: para superar este obstáculo histórico del acceso integral a la salud, como derecho humano fundamental, es necesario superar las decisiones políticas y administrativas que obstaculizan la construcción del SUS legítimo, en una participación verdaderamente democrática de todos los actores sociales.

Descriptores: Derecho a la Salud; Accesibilidad a los Servicios de Salud; Atención Primaria de Salud; Sistema Único de Salud; Enfermería. 


\section{INTRODUCTION}

Social rights, such as the right to health ${ }^{(1)}$, considered a fundamental human right ${ }^{(2)}$, determine a demarcation of the expansion of citizenship in postmodern societies, since it "claims the State's action and attaches new principles to the development of citizenship standards, in particular different ways of understanding the meaning of satisfying a decent level of well-being and economic and social security"(3). What goes beyond the absence of the disease and also includes health determinants and determinants such as access essential goods and services such as health, education, food, work and fair income, housing, body practice, culture and leisure, drinking water, solid waste collection, sewage collection and treatment, transportation ${ }^{(4)}$.

Health as a right of citizenship implies universal, comprehensive and equal access to the Unified Health System (SUS - Sistema Único de Saúde), established in the Constitution of the Brazilian Federative Republic ${ }^{(1)}$. But in more than 30 years of SUS implantation "we also seek to make these principles effective in the daily life of services"(5).

For this effectiveness, the Family Health Strategy (FHS) was implemented in 1994, as a priority door for the reorganization of the care logic centered on the family, aiming at changes in fragmented, individual and disease-centered care ${ }^{(5)}$.

PHC teams must develop actions based on their territorial base with the highest degree of decentralization and capillarity, allowing access to the place closest to people's lives, the creation of bonds and person-centered care ${ }^{(6)}$.

This access must be guaranteed to users by the appropriate and timely use of services and actions in view of their needs, with care without any discrimination, welcoming and humanized. Therefore, it can be said that health is the right of all. For Maffesoli( ${ }^{(7)}$ "common sense, in its ancestral wisdom, is not disturbed by the duty to be and, thus, recognizes what it is or is". SUS is for everyone without distinction. Thus, in addition to the right to access, SUS users need to be respected in their human dignity, autonomy and values. However, they must be responsible for proactive participation in the production of individual and collective health.

The notion of access can be related to daily life "and health work processes, to the organization of the Health Care Network (RAS - Rede de Atenção à Saúde), to the system and to the care model. Criticisms of access conditions in SUS address the difficulties of this system, with RAS organization being the main target of discussions ${ }^{\prime \prime(8)}$. In the background, advances, limits and challenges are considered as the System's logic, "defining the care model, which organizes access to services, as well as the responses to the needs arising from social determinants of health, demographic transitions and epidemiological and the role of social control in effecting the right to health"(8).

Considering the historical milestone of more than 30 years of SUS, this study is justified by seeking, from users' perspective, understanding the right to health and their experiences of access in PHC. When considering PHC as SUS setting for this study, the guideline of care coordination is claimed in order to plan and organize the flow accompanying users in care in health and intersectoral, public, community and social networks ordering them, contributing to planning actions, scheduling services based on people's health needs ${ }^{(6)}$. Thus, it sought the notion of access to the System, as a right, through the eyes of those who are at its entrance door, $\mathrm{PHC}$, which should be the preferred one.

Thus, one wonders: How do users understand the right to health? How do users experience access to health within SUS context, with PHC as a gateway?

\section{OBJECTIVES}

To understand access in a day in the life of Primary Health Care as a fundamental right to health, from users' perspective.

\section{METHODS}

\section{Ethical aspects}

This study was approved by the Ethics Committee of Universidade Federal de São João del-Rei, Center-West Campus. It was developed according to the Brazilian National Health Council Resolution (Conselho Nacional de Saúde) 466 of December 12, 2012. It complied with the guidelines and regulatory standards for research involving human beings and taking into account the pertinent ethical and scientific foundations.

\section{Theoretical-methodological framework}

Michel Maffesoli's Comprehensive Sociology of Everyday Life theoretical framework ${ }^{(7)}$ was used to understand access and accessibility in the daily life of PHC through plurality of views and experiences of SUS users, occupying themselves in describing " what has been lived for what it is, contenting itself with discerning the views of the different actors involved"(7). It makes it possible the description of postmodern living ${ }^{(7)}$, considering everyday life as the "ways of life, ways of being, thinking, situating, behaving towards others and nature"(9). Thus, "daily life is the object of study in the different research scenarios in Nursing and Health, not only as a synonym for day to day, but also, as an expression of a way of living in a given context"(10).

The holistic multiple case study methodological framework ${ }^{(11)}$ enabled the understanding of the object of analysis, gathering numerous and detailed information in order to seize the researched realities. Associated with the qualitative approach, this method makes it possible to understand, explore, describe or explain a phenomenon in its natural context, contributing to its global understanding and interpretation ${ }^{(11-12)}$.

Understanding access in PHC daily from the perspective of SUS users can be based on Maffesolian conception, referring to how various parts of a phenomenon are ordered and how the forces involved in this ordering are connections that occur internally to them ${ }^{(7)}$.

\section{Type of study}

This is a qualitative study under the Holistic Multiple Case Study method ${ }^{(11)}$ based on the Comprehensive Sociology of Everyday Life ${ }^{(7)}$. This study considered the recommendations of the COnsolidated criteria for REporting Qualitative research (COREQ) guidelines ${ }^{(13)}$. 


\section{Methodological procedures}

This study contains two cases, defined by two municipalities in Minas Gerais, Brazil. Each case involved an empirical and complete investigation $^{(11)}$ of the contemporary phenomenon within the context of real life, in which convergences and divergences in the evidence of the facts were sought to conclude the cases ${ }^{(11)}$ of this study. This study, for being holistic, had as a single unit of analysis, for both cases "access in the daily routine of Primary Health Care as a fundamental right to health".

Multiple case studies have the ability to generalize to theoretical propositions, so they can expand and generalize theories (analytical generalization) $)^{(11)}$.

\section{Study setting and research participants}

The universe of this study consisted of two municipalities in the state of Minas Gerais, Brazil. To compose the scenario, Traditional $\mathrm{PHC}$ units and units with FHS teams were randomly drawn, and comprised, equally, three Traditional PHC units and three FHS units in the urban area of the two municipalities (Field Notes - FN).

Municipality 1 (10,547 inhabitants and 100\% FHS coverage) has two rural districts. The population is registered and served in four health units, one of Traditional PHC and three of FHS, these teams incorporate the dental surgeon, the oral health assistant and have the support, on alternate days, of pediatricians, nutritionists, gynecologists, speech therapist, physiotherapist, occupational therapist. In the FHS units, they have night-time clinical care, once a week, for the working class. The Traditional APS, located in the city center, is a reference for the population of the municipality to attend specialized consultations of pediatricians, gynecology, obstetrics, cardiology, neurology, general surgery, orthopedics, urology (FN).

In municipality 2 (234,937 inhabitants, 32\% ESF coverage), has 64 health institutions, including 01 Regional Emergency Care Unit, 11 Traditional PHC Units, 32 FHS teams, 01 Polyclinic, 01 Psychosocial Care Center (CAPS-Centro de Atenção Psicossocial) with the services of Psychiatric Outpatient Service, Psychiatric Emergency and 01 CAPS AD III, 01 Immunization Center, 07 basic pharmacies, 01 Regional Rehabilitation Center, 01 Health Surveillance Unit, 01 Specialized Dentistry Service, 03 Mobile Emergency Service Units, 03 auxiliary diagnostic and therapy services, in addition to 16 specialized services and 03 hospitals that have complementary participation to SUS (FN).

This study had as inclusion criteria people $\geq 18$ years of age and that they can answer for themselves. Eighteen SUS users from municipality 1 and 59 from municipality 2 voluntarily participated. In a total of 77, 57 women and 20 men, the average age was 41 years old, most had completed high school. Seven people refused to participate in this study.

\section{Data source}

The sources of data were the intensive open interview, the FN, the visit to the FHS and Traditional PHC Units. Open interview, with a semi-structured script, addressed the characteristics of the research participant, health care, reference services for health care, monitoring by the PHC/FHS health team, about users' understanding of SUS, health care, PHC access and right to health. FN were directed to the operational procedures of the research, detailing the characteristics of the municipalities, about visits to $\mathrm{PHC} / \mathrm{FHS}$ units and the relevant facts of data collection.

\section{Data collection and organization}

The period of data collection was between April and September 2017. The approach of the research participants, coming from programmed or spontaneous demands, was in the waiting room of the PHC/FHS unit. The invitation was made after the user presented himself at the reception of the health unit and the interview was carried out after he had been seen in a consultation or procedure.

The interview was conducted in a private room at the health unit, after presentation of an Informed Consent Form, audio recorded, with an average duration of eight minutes. Data saturation by literal replication ${ }^{(11)}$ occurred in the 77 th interviewee. To guarantee the anonymity of the participants and the confidentiality of the information, the letter "E" (interviewee) was used, sequenced by the cardinal number of the interview.

\section{Data analysis}

Thematic content analysis considering the semantic analysis according to pre-analysis, material exploration, treatment of results, inference and interpretation ${ }^{(14)}$, obeying the analytical technique of case cross synthesis ${ }^{(11)}$.

Pre-analysis aimed to operate and systematize the ideas in a procedural and successive way. The first activity carried out was skimming, which consisted of recognizing the text, allowing itself to be invaded by impressions and orientations, so that, little by little, the reading became more accurate and comprehensive $\mathrm{e}^{(14)}$.

Material exploration consisted of coding and categorizing the data obtained. Coding was performed by "coding operations"(14), according to the rules formulated. This codification "is the transcription of specific characteristics, allowing to achieve a representation of the content or its expression"(14). It is the effectiveness of the decisions taken in pre-analysis, i.e., what represents the meanings expressed in the fluctuating, precise and comprehensive reading.

Categorization consisted, first, in classifying textual elements by differentiation and, later, by grouping, through the common characteristics or meanings of these elements ${ }^{(14)}$.

In material exploration by coding, the indexes were referenced and the registration units were elaborated. These indexes were determined according to each subject related to the right to health, access or its dimensions, which were converged into groups, which formed subcategories and contain subgroups within them. That is, compilation of data by approximation of meanings, by convergence of data, i.e., replication ${ }^{(11)}$ in research participants' speeches.

Considering, also, material exploration, categorization was made, which consisted of classifying and grouping certain subjects due to divergences or convergences of the results ${ }^{(14)}$. Two thematic categories originated: SUS-30 years: right and access 
in a day in the life of Primary Health Care; and SUS in the lives of Brazilians: care, accessibility and equity in the daily lives of Primary Health Care users.

The last phase consisted in the treatment of results, inference and interpretation ${ }^{(14)}$. I.e., first, there was a grouping of the data obtained, progressing to logical conclusions, which for this article was about the right to health and access in the daily routine of PHC from users' perspective, and the discussion using scientific literature, thus leading to interpretations and description of the study results.

\section{RESULTS}

The right to health in users' voice is what is constituted, lived and idealized:

But if it is right you have to look for it, right? If you pay your taxes you are entitled. As a public servant, I see that they from Health have the same function that we have, which is the service. I believe in SUS a lot, okay? I really believe that if the Brazilian really fought, it would be the biggest system to be followed. And how we have a habit of complaining! But abroad, they see very well that we have a health system that still works better than in many countries. We cannot complain, we must also look at the positive side. It's difficult? It's sometimes difficult to get an appointment, but you can get. (I9)

What do I understand? A uniform service for everyone... because the name itself is already indicating: Unified Health System. Something that everyone is entitled to and that is uniform for everyone. That's basically it, it's what it should be, exactly! [...] everyone has the right to good and dignified service, equal to all. Something that is really necessary, that is part of the dignity of the person, that I consider as basic, as primordial. (I26)

The right is in the constitution, it is guaranteed for every Brazilian. So, if it is not being met, the constitution is not valid, it is only on paper. The Brazilian should be given more conditions, especially children, the elderly, the disabled, and people who have to pay expensive treatment. (127)

I understand very little, I don't understand. I think the right to health is for everyone who needs it. No, this is not how it happens, not everyone is assisted, there are some who have more priorities than the others, I can't explain why, but there are. (149)

When referring to the system, study participants address the law, their opinion and the published opinion on SUS:

It is not being what they wanted it to be. On television they show one thing, but, in reality, it is another. (I1)

Likewise, the person does not even have a simple consultation, and it is the person's right and does not have it. We see a lot on television. That there is no place [...] the person comes to consult and there is no physician, there is no pediatrician. Here, I am not saying that it is not the best city, but in view of many cities [...] if it is to compare, I still give glory to God, and it will get better. (152)

User feelings arise in relation to SUS care in view of the need answered or the lack of response:
I wanted it to be faster because sometimes you have to wait and that waiting is lost a little. But I feel fulfilled, all the assistance I needed arrived. The solution always arrives. (19)

I feel good, do you know why? I have nowhere else to turn. When I found out I had cancer, I depended a lot on other things, like cancer support houses, they helped me a lot. But SUS also helped me a lot. So, I have nothing to complain about, not very satisfied with SUS. (144)

Ah! A neglect, a lot of neglect, a lot of neglect [...] it doesn't get there. I'm getting discouraged, thinking of leaving and leaving the consultation aside, I'll stay here waiting and suddenly the girl comes and says: there isn't. You have to give priority to the case you have with more urgency, so you are like that [...] impotent, right? (148)

For me, SUS is a shame, a disregard for the people who need it most. (150)

Users' feelings towards employees and health professionals when being assisted points out that having attention, education, knowing how to dialogue and welcome is directly related to what they idealize for the system or what they want to receive in response and care. When the service contradicts what is expected as a welcoming, the user reports:

There are some [professionals] who are very rude, they assist us with rudeness, you know? The wait is also sometimes inside. (122)

Idon't have to complain, thank God. Ah, because they are thoughtful. They try to assist us when they need it. When I need to take an exam, they book, take it there for me. (I24)

There was a physician there that I didn't like him. He answered and didn't even look at people's faces, you know? Yeah, but it's already gone. Now there's another physician. (143)

In the days of data collection while waiting at the reception of the PHC/FHS units for the opportunity to approach the user and the time to interview him, there was a diversity of user demands for access to actions and services, including referrals to secondary care, care spontaneous demand, scheduling appointments and exams. Limits were found related to accessibility and the process of welcoming users due to the lack of an appropriate place and adequate approach and scarcity/lack of available resources, as well as the reactions and emotions of users towards responsible attention, with resoluteness and quality (FN).

\section{DISCUSSION}

According to users' voice, the right to health is still a matter of struggle, as literal replication in both cases of this study. In order to obtain accessibility to certain services and actions, a user's commitment is necessary, but the participants portray that SUS is the place where they have to resort. User reports move from ease to difficulty of access, but, despite the inequality in relation to the offer of services, the solution always arrives. In obtaining access to comprehensive health care, users experience situations laden with needs to be answered, and, at times, difficulties/delays 
in care, "what constantly calls us to look, in the most varied ways and in the most varied times, a world of being together full of delicacies: of sufferings, complaints, murmurs, which stand between the self and the other, and which do not obey to an order in everyday life"(15).

The right to health, constituted and instituted, was expressed by users participating in this study. A study carried out in Fortaleza, Ceará, Brazil, with 67 participants, $89.5 \%$ from Fortaleza and $10.5 \%$ from the countryside of the state of Ceará, found that $67 \%$ (45) of interviewees said they did not know the right to health guaranteed by the Constitution of the Federative Republic of Brazil, eight (11\%) were aware of the laws of the public health system, SUS, and (58.2\%) of the participants did not show credibility for better care if they sought private care ${ }^{(16)}$. "Lack of knowledge is one of the factors to be considered for the realization of the right to health in Brazil. There is still a lack of knowledge about health rights by most SUS users"(16), which distances citizens from participation and social control within the scope of SUS.

The approach of the participants of this study contemplates that SUS was structured as unique and universal, with principles of comprehensiveness and equity, and that it should be more resolutive and respond to the health needs of people in full. A study carried out in Divinópolis, Minas Gerais, Brazil, identifies that PHC is understood as the preferred contact of users and that it should be oriented towards integral and equitable care, offering the most diverse actions and procedures considering the unique needs. But even with the preferential door open, there is fragmentation of the actions and services that make up RAS, users seek immediate solutions to their problems and the population lacks adherence to preventive practices ${ }^{(17)}$.

A study carried out in Recife, Brazil, with 46 users, points out as limits to access to health, underfunding, insufficient FHS coverage, lack of supplies, shortage of physicians and other professionals, long waiting time for consultation and exams ${ }^{(18)}$.

Over more than three decades, SUS has been suffering from the decrease in the federal budget, which is due to the untying of the Federal Revenue and freezing of expenses for the next 20 years in Constitutional Amendment 95/2016, which will reach $30 \%$ of the percentage less in 2023 . Other threats are the direct or indirect participation and control of foreign capital in health established in Law 13.097/2015 and PEC 451, which aims to compel the employer to offer workers a private plan $^{(19)}$. These threats damage the health budget and social policies, narrowing access to health as a human and constitutional right. But we have to resist the threats, according to the participants in this study, and fight because we have a health system that still works better than in many countries.

The general population still attributes that there is a resource, that the problem of SUS is corruption. However, there is a need for transparency and to demonstrate that the problem is underfunding ${ }^{(20)}$.

The availability of health professionals in PHC/FHS makes it possible to assess the growth in the supply of these resources through FHS expansion; however, according to some participants in this study, the experiences are linked to lack of physicians, consultations, exams, professional attention, and education to approach users. A study ${ }^{(21)}$ carried out with $\mathrm{PHC} / \mathrm{FHS}$ health professionals on the daily work in $\mathrm{PHC}$ at 30 years of SUS points out that, in their daily lives, they find it difficult to respond to users' demands or refer them to other levels of complexity, in due time, due to the scarcity of resources "This reality, linked to the precarious working conditions of professionals, causes insecurity for their performance"(21).

The limitations of access and the difficulties faced by FHS teams from three municipalities in Minas Gerais, Brazil, show low resolvability, opposite the dependent SUS population, high number of registered people and low population coverage, lack of $\mathrm{CHW}$, ineffectiveness of management and scarcity of scheduled actions. The study indicates that health professionals, users and managers should, in a collaborative way, seek strategies to cope with the difficulties of access and the high spontaneous demand in the daily services ${ }^{(22)}$.

From FHS users' perspective, a study carried out in the Federal District, Brazil, shows that the system is not yet prepared to meet their needs, which constitutes a barrier to access, but that when they are able to enter SUS they can take advantage of various services ${ }^{(23)}$.

For Mafessoli (24), "somehow, man acts because he dreams of acting. Imagination is also the aura of an ideology, because, in addition to the rationale that composes it, it involves a sensitivity, the feeling, the affective". In addition to the legal framework that constitutes SUS as a space for citizens' right to health, human beings cry out for attention, care and dignified treatment that includes subjectivity.

In this SUS setting, we must be more active and fighting to fully consolidate health as a right for everyone ${ }^{(25)}$, as evidenced in this study: if the Brazilian really fought, it would be the greatest system to be followed, but we have a habit of complaining. "The strength of our public health policy is the concrete SUS, it is the extension of benefits brought to the population, and its weakness is also SUS that really exists, with all its problems and shortcomings"(26). According to Lígia Bahia et al. ${ }^{(19)}$, "I would say that SUS is the way, and SUS has no way".

According to participants, access and use of health services has a daily trajectory of waiting, as resources are lacking. It is necessary to continue to fight underfunding SUS and the motto that health as a right does not fit into the public budget, and that only the reduction of public spending, in postmodern capitalism, drives social growth, and the guarantee of rights will be the result ${ }^{(25)}$.

The users participating in this study declare public and published opinions about SUS; between the lines expose that the system is not being as it was conceived, bringing neglect in the face of their needs, but at the same time they place SUS as the public health space they have to resort to in the face of health and disease. According to Gastão Wagner de Sousa Campos ${ }^{(26)}$, "since SUS is intended, in practice, the majority of the population exploited, the consideration of health problems and the quality of health services is, to a large extent, similar to neglect how these people are treated".

"Nunca o SUS foi tão grande em sua história e, no entanto, nunca esteve tão frágil"(27). It is a fact that the advances made by SUS are realized in the daily life of Brazilians in $\mathrm{PHC}$ by linking more than $60 \%$ of the population to FHS teams, in access to immunization and pharmaceutical assistance, in transplants, in SAMU and in the control of smoking, HIV/AIDS and blood quality. As well as 
in the development of health information systems referring to mortality, hospital admissions and health problems, relevant to monitoring and assessing policies, plans, and programs ${ }^{(28)}$.

We are left with a common good: to continue the democratic construction of SUS. The time is, perhaps, more attentive to this impermanence of the more established things, "prefers to continue to manage a known institute rather than a possibly dangerous one $^{\prime \prime(9)}$. Participation in defense of SUS goes beyond the ideals of a constituted system, it turns to a right to life with quality and in respect for the dignity of humans with health.

In addition to users, health professionals need to act, in a committed way, in defense and strengthening of SUS, ensuring universal, comprehensive, equitable care and the transformation of the population's life and health reality.

Democratic popular participation becomes imperative, through effective representations in councils. Participation has been a mainstay for facing challenges in this process of building SUS for over 30 years. A participating population can bring about changes to achieve social justice, equality, solidarity and guarantee health and dignity of life ${ }^{(25)}$.

\section{Study limitations}

The limitation of this study is found in the sampling to be intentional, by including as users those present in PHC/FHS units on the day of data collection, representing only a subset of the user population. But under similar conditions in multiple case studies with data saturation by literal replication, intentional sampling can be considered representative(11).

\section{Contributions to nursing and health}

This study presents contributions to health and nursing by understanding access in the daily life of PHC as a fundamental right to health, from users' perspective, and can be a source of reflections and subsidies for the organization and planning of daily work in PHC with a view to achieving universal access, with comprehensive and equitable actions to guarantee the dignity of users' lives, citizens with the right to health. Thus, the findings of this study have the potential to extend to similar situations, conferring the capacity for external generalization in holistic-qualitative multiple case studies.

\section{FINAL CONSIDERATIONS}

Believing in SUS and having SUS, recognizing health as a fundamental right to life with dignity, is not enough for users, because what is constituted needs to be experienced in the daily life of health services.

SUS is the open and unique door for almost all of 77 participants in this study, in a conception that it is not a free system, when presenting what attributes are guaranteed arising from contributions and taxes collected from the Brazilian population, to maintain this social right, among others. So, according to users' voice, it is necessary to seek because it is a constituted right, to fight and not only complain about what is not yet real in SUS and was idealized.

In daily life, there is evidence of neglect, resulting in limits for the dignified reception of users and resolutive actions. However, there is mention of responsible and quality care, demonstrating everyday experiences that are similar to other Brazilian realities.

To overcome this historic obstacle of full access to health, as a fundamental human right in a single and public system, is it necessary to recognize and deal with underfunding and the scarcity of infrastructure or overcome political and administrative decisions that hinder the construction of legitimate SUS, in a truly democratic participation of all social actors?

\section{REFERENCES}

1. República Federativa do Brasil (BR). Constituição 1988. Constituição da República Federativa do Brasil [Internet]. Brasília: Senado Federal; 1988[cited 2020 Jun 10]. 133-4 p: Seção II. Available from: http://www.planalto.gov.br/ccivil_03/constituicao/constituicao.htm

2. Organização das Nações Unidas (ONU). Pacto internacional de direitos econômicos, sociais e culturais. Adotada pela Resolução n.2.200-A (XXI) da Assembleia Geral das Nações Unidas, em 16 de dezembro de 1966 e ratificada pelo Brasil em 24 de janeiro de 1992 [Internet]. 1966[cited 2020 Jun 10]. Available from: https://www.oas.org/dil/port/1966\%20Pacto\%20Internacional\%20sobre\%20os\%20Direitos\%20 Econ\%C3\%B3micos,\%20Sociais\%20e\%20Culturais.pdf

3. Barros FPC, Sousa MF. Equidade: seus conceitos, significações e implicações para o SUS. Saúde Soc. 2016; 25(1):9-18. https://doi. org/10.1590/S0104-12902016146195

4. Presidência da República (BR). Lei no. 8.080 de 19 de setembro de 1990. Dispõe sobre as condições para a promoção, proteção e recuperação da saúde, a organização e o funcionamento dos serviços correspondentes, e dá outras providências [Internet]. Diário Oficial da União 1990[cited 2020 Jun 10]. Available from: http://www.planalto.gov.br/ccivil_03/leis/l8080.htm

5. Viegas SMF, Penna CMM. Integrality: life principle and right to health. Invest Educ Enferm. 2015;33(2):237-47. https://doi.org/10.17533/udea. iee.v33n2a06

6. Ministério da Saúde (BR). Portaria n 2.436, de 21 de setembro de 2017. Aprova a Política Nacional de Atenção Básica, estabelecendo a revisão de diretrizes para a organização da Atenção Básica, no âmbito do Sistema Único de Saúde (SUS) [Internet]. Diário Oficial da União, Brasília (DF), 21 set 2017[cited 2020 Jun 10]. Available from: https://bvsms.saude.gov.br/bvs/saudelegis/gm/2017/prt2436_22_09_2017.html

7. Maffesoli M. O conhecimento comum: introdução à sociologia compreensiva. Porto Alegre: Sulina, 2010. 295 p.

8. Barbiani R, Junges JR, Nora CRD, AF. A produção científica sobre acesso no âmbito do Sistema Único de Saúde do Brasil: avanços, limites e desafios. Saúde Soc. 2014;23(3):855-68. https://doi.org/10.1590/S0104-12902014000300010 
9. Maffesoli M. O tempo retorna: formas elementares da pós-modernidade. Tradução de Teresa Dias Carneiro; revisão técnica de Abner Chiquieri. Rio de Janeiro: Florense Universitária, 2012.

10. Nitschke RG, Tholl AD, Potrich T, Silva KM, Michelin SR, Laureano DD. Contributions of Michel Maffesoli's thinking to research in nursing and health. Texto Contexto Enferm. 2017;26(4):e3230017. https://doi.org/10.1590/0104-07072017003230017

11. Yin RK. Estudo de Caso: Planejamento e Métodos. Bookman editora, 2015. 290p.

12. Minayo MCS. Los conceptos estructurantes de la investigación cualitativa. Salud Colectiva. 2010;6(3):251-61. https://doi.org/10.18294/ sc.2010.283

13. Tong A, Sainsbury P, Craig J. Consolidated criteria for reporting qualitative research (COREQ): a 32-item checklist for interviews and focus groups. Int J Qual Health Care. 2017:19(6):349-57. Available from: https://www.equator-network.org/reporting-guidelines/coreq/

14. Bardin L. Análise de conteúdo. São Paulo: Edições 70; 2011.

15. Viegas SMF, Penna CMM. As dimensões da integralidade no cuidado em saúde no cotidiano da Estratégia Saúde da Família no Vale do Jequitinhonha, MG, Brasil. Interface (Botucatu). 2015;19(55):1089-100. https://doi.org/10.1590/1807-57622014.0275

16. Silva Jr GB, Dias ER. Avaliação da satisfação dos usuários de um serviço de saúde público-privado no nordeste do Brasil e a judicialização da saúde. Rev Direito Sanit. 2016;17(2):13-29. https://doi.org/10.11606/issn.2316-9044.v17i2p13-29

17. Melo DF, Criscuolo MBR, Viegas SMF. Reference and counter-reference in everyday health care in Minas Gerais, Brazil: the support to decisions of primary care. Rev Pesqui: Cuid Fundam. 2016; 8(4):4986-4995. https://doi.org/10.9789/2175-5361.rpcfo.v8.4402

18. Lima SAV, Silva MRF, Carvalho EMF, Pessoa EAC, Brito ESV, Braga JPR. Factors that influence access to primary care in the perspective of professionals and users of a health services network in Recife-PE, Brazil. Physis. 2015; 25(2):635-56. https://doi.org/10.1590/ S0103-73312015000200016

19. Giovanella L, Mendoza-Ruiz A, Pilar ACA, Rosa MC, Martins GB, Santos IS, et al. Sistema universal de saúde e cobertura universal: desvendando pressupostos e estratégias. Ciênc Saúde Coletiva. 2018;23(6):1763-76. https://doi.org/10.1590/1413-81232018236.05562018

20. Bahia L, Cueto M, Benchimol J, Teixeira LA, Cerqueira RC. Considerations on the Sistema Único de Saúde in the twenty-first century: an interview with Lígia Bahia. Hist, Ciênc, Saúde Manguinhos. 2014; 21(1):93-107. https://doi.org/10.1590/S0104-59702014000100005

21. Gontijo MD, Viegas SMF, Freitas ATS, Maia AFF, Nitschke RG, Nabarro M. Atuação cotidiana no Sistema Único de Saúde em sua terceira década. Esc Anna Nery. 2020;24(4):e20190350. https://doi.org/10.1590/2177-9465-ean-2019-0350

22. Chávez GM, Viegas SMF, Roquini GR, Santos TR. Acesso, acessibilidade e demanda na estratégia saúde da família. Esc Anna Nery. 2020;24(4):e20190331. https://doi.org/10.1590/2177-9465-ean-2019-0331

23. Shimizu HE, Ramos MC. Avaliação da qualidade da estratégia saúde da família no Distrito Federal. Rev Bras Enferm. 2019;72(2):367-74. https://doi.org/10.1590/0034-7167-2018-0130

24. Maffesoli M. O imaginário é uma realidade. Rev Famecos. 2001;15:74-82. https://doi.org/10.15448/1980-3729.2001.15.3123

25. Santos L. SUS-30 anos: um balanço incômodo? Ciênc Saúde Coletiva. 2018;23(6):2043-50. https://doi.org/10.1590/1413-81232018236.06082018

26. Campos GWS. SUS: o que e como fazer? Ciênc Saúde Coletiva. 2018; 23(6):1707-14. https://doi.org/10.1590/1413-81232018236.05582018

27. Santos RT. SUS: um novo capítulo de lutas. Ciênc Saúde Coletiva. 2018;23(6):1719-20. https://doi.org/10.1590/1413-81232018236.05672018

28. Paim JS. Sistema Único de Saúde (SUS) aos 30 anos. Ciênc Saúde Coletiva. 2018;23(6):1723-28. https://doi. org/10.1590/1413-81232018236.09172018 